\title{
RELAÇÕES DIALÓGICAS NO DISCURSO ACADÊMICO-CIENTÍFICO DOS ARTIGOS DAS DIFERENTES ÁREAS DO CONHECIMENTO
}

\section{DIALOGIC RELATIONS IN SCIENTIFIC AND ACADEMIC DISCOURSE OF ARTICLES IN DIFFERENT AREAS OF KNOWLEDGE}

Ângela Francine Fuza"18

\begin{abstract}
RESUMO: Artigos científicos brasileiros de periódicos A1 das diferentes áreas do conhecimento foram analisados a fim de verificar as relaçōes dialógicas presentes no discurso acadêmico-científico. Para isso, o estudo adotou como aporte teóricometodológico a concepçăo dialógica de linguagem (BAKHTIN, 2003; BAKHTIN/ VOLOCHINOV, 1992), segundo os princípios teóricos da Linguística Aplicada. Nos textos, foram identificados sete tipos de relaçōes dialógicas: diálogo com o conhecimento científico consensual; concordância com discursos alheios; discordância dos discursos alheios; marca de novidade; relaçăo de pergunta e resposta; relaçăo de questionamento da teoria existente; inserçăo na comunidade científica. Os resultados evidenciam que as relaçóes dialógicas mais recorrentes nos artigos das áreas sâo a inserçăo na comunidade científica, o diálogo com conhecimento científico consensual e a marca de novidade. Isso demonstra que a pretensa objetividade do discurso científico é um instante que organiza o enunciado, todavia, năo constitui o todo, pois todo discurso é dialógico por natureza, tendo em vista que os sujeitos-pesquisadores, atuantes em suas comunidades, interagem e vivenciam o dialogismo do discurso científico na elaboraçáo do conhecimento.
\end{abstract}

Palavras-chave: Relaçôes dialógicas; discurso acadêmico-científico; artigo científico.

ABSTRACT: Brazilian scientific articles A1 from different areas of knowledge were analyzed in order to verify the dialogic relations present in the scientific and academic discourse. For this, the study adopted the dialogic conception of language (Bakhtin, 2003; Bakhtin/Volochinov, 1992) as a theoretical and methodological support, according to the theoretical principles of Applied Linguistics. Through the analysis of texts, we identified seven types of dialogic relations: dialogue with the consensual scientific knowledge; agreement with other people"s discourses; disagreement of others" discourses; mark of novelty; question and answer relationship; existing theory questioning relationship; insertion in the scientific community. The results show that the most recurrent dialogic relations in the areas of the articles are the inclusion in the scientific community, dialogue with consensual scientific knowledge and mark of novelty. This shows that the alleged objectivity of scientific discourse is a moment

118 Doutora em Linguística Aplicada (Unicamp), professora da Universidade Federal do Tocantins. Pesquisa desenvolvida com apoio financeiro do CNPq. Correio Eletrônico: angelafuza@uft.edu.br. 
that organizes the statement, however it is not all, because all discourse is dialogical in its nature, given that the subject-researchers, active in their communities, interact and experience the dialogism of scientific speech in the development of knowledge.

Keywords: Dialogic relations; scientific and academic speech; scientific article.

\section{CONSIDERAÇÕES INICIAIS}

A noçăo de linguagem racionalista pressupóe uma suposta objetividade absoluta, sendo que o ato enunciativo é constituído de dimensōes monológicas e dialógicas (CORTES, 2009). Nesta perspectiva, Sobral (2009, p. 30) assinala que "o sujeito, ao agir, deixa por assim dizer uma "assinatura" em seu ato e por isso tem de responsabilizar-se pessoalmente por seu ato e se responsabiliza por ele perante a coletividade de que faz parte". Cada sujeito é único em termos de feitio subjetivo, mas também sua atividade responsiva se circunscreve aos seus limites socioformativos em determinados domínios da cultura. Logo o fazer científico, ao mesmo tempo em que é constituído pelo individualismo do pesquisador, é perpassado por normas, por princípios e por convençóes de escrita da comunidade científica da qual o sujeito é membro.

No entendimento de Cortes (2009) e de Amorim (2004), ao adentrar no pensamento bakhtiniano a respeito do monologismo e do dialogismo, compreende-se que săo momentos distintos (mas nâo estanques) que compóem o todo do ato da criaçăo científica. Isso porque, ao adotar o viés dialógico de linguagem, năo há significativa recusa do texto monológico, haja vista que o monologismo do texto científico é "uma abstraçăo necessária à construção do objeto de estudo, ou momento de exotopia" (CORTES, 2009, p. 6).

Assim, a pretensa objetividade do discurso científico é um instante que organiza o enunciado, todavia, năo constitui o todo. Para Cortes (2009, p. 7), o fato de "admitir a dimensăo monológica do discurso científico năo significa negar o caráter dialógico dessa modalidade discursiva". Um enunciado, como uma obra científica, por mais focada que seja em seu objeto, caracterizando uma forma monológica, ainda assim, é uma resposta ao discurso anterior.

Os sujeitos-pesquisadores, atuantes em suas comunidades, interagem e vivenciam o dialogismo do discurso científico com os teóricos estudados e na elaboraçấo do conhecimento. Em cada época e círculo social, os enunciados săo produzidos, perpassados de autoridade, servindo de base para a origem de novos textos, uma vez que o enunciado "cria algo que ainda năo existia antes dele, absolutamente novo e singular, e que ainda por cima tem relaçấo com o valor. [...] todo o dado se transforma em criado" (BAKHTIN, 2003, p. 326). As comunidades científicas săo, portanto, essencialmente dialógicas, necessitando do outro para que existam, haja vista que "nenhuma oraçáo, mesmo a de uma só palavra, jamais pode repetir-se: é sempre um novo enunciado (ainda que seja uma citaçăo)" (BAKHTIN, 2003, p. 313).

Tendo em vista o diálogo estabelecido entre diferentes vozes no interior dos artigos das diferentes áreas do conhecimento, caracterizando-os como dialógicos e 
heterogêneos, este texto ${ }^{119}$ objetiva analisar as relaçôes dialógicas estabelecidas nos discursos acadêmico-científicos presentes em artigos de periódicos nacionais A1 das diferentes áreas do conhecimento - Ciências Humanas, Ciências Exatas e da Terra, Ciências da Saúde, Ciências Sociais, Engenharias, Linguística, Letras e Artes. Dessa forma, dois objetivos săo delineados: a) destacar os tipos de relaçóes dialógicas presentes nos discursos das diferentes áreas; b) evidenciar a dialogicidade do discurso científico, marcado pela heterogeneidade discursiva.

Para tal, o aporte teórico-metodológico convocado para as reflexóes propostas na investigaçăo é a concepçăo dialógica de linguagem (BAKHTIN, 2003; BAKHTIN/ VOLOCHINOV, 1992), segundo os princípios teóricos da Linguística Aplicada.

Este texto, vinculado aos grupos de pesquisa: "Interaçăo e Escrita" (UEM-CNPq - www.escrita.uem.br) e "Escrita: ensino, práticas, representaçōes e concepçôes" (Unicamp) e ao projeto de pesquisa: "Práticas de letramento acadêmico-científicas: a constituiçăo dos discursos escritos" (UFT), discorre, primeiramente, a respeito das relaçôes dialógicas e das vozes bakhtinianas. Na sequência, destaca a seçâo metodológica e a análise dos dados observados.

\section{RELAÇÕES DIALÓGICAS E VOZES BAKHTINIANAS: BREVES CONSIDERAÇÕES}

A noçâo de relaçôes dialógicas é mencionada desde a obra Marxismo e Filosofía da Linguagem (BAKHTIN/VOLOCHINOV, 1992), postulando-se que a interaçâo verbal é elemento fundamental da comunicaçáo, sendo concretizada por meio dos processos de compreensâo e responsividade ativas, levando ao diálogo.

Bakhtin, em Problemas da Poética de Dostoiévski (2002), trata dos elementos envoltos pela noçâo da interaçâo verbal. Para o autor, as relaçôes dialógicas se referem às relaçôes semânticas instituídas entre enunciados concretos de distintos sujeitos do discurso. Tais relaçōes envolvem năo só questóes lógicas e sintáticas de natureza léxico-semânticas, mas também influências externas, ou seja, fatores extralinguísticos, por exemplo, situaçáo de enunciaçấo, compreendendo diferentes sujeitos do discurso, as esferas de circulaçăo, o gênero, o estilo etc. É possível afirmar ainda que nessas "relaçóes dialógicas é estabelecido um diálogo do autor com o enunciado do outro presente em seu discurso" (SANCHES, 2009b, p. 3), vendo-o como uma forma de opiniăo e náo como algo objetificado.

Um dos princípios que norteiam as relaçōes dialógicas é a alteridade, pois o enunciado se concretiza em virtude do interlocutor real ou presumido. O outro é inserido no enunciado, havendo sempre enunciados alheios dentro dele, pois "cada enunciado é pleno de ecos e ressonâncias de outros enunciados com os quais está ligado pela identidade da esfera de comunicaçáo discursiva" (BAKHTIN, 2003, p. 297).

Ao se tratar da presença do outro no enunciado, Amorim (2004) afirma que a alteridade marca as fronteiras do discurso, permitindo o acabamento do enunciado ao se passar a palavra ao outro, "náo há sentido fora da diferença, da arena, do confronto,

119 Texto baseado nas investigaçóes que compóem a tese de Doutorado da autora (FUZA, 2015). 
da interaçâo dialógica, e assim como năo há um discurso sem outros discursos, năo há eu sem outro, nem outro sem eu" (SOBRAL, 2009, p. 39). O locutor, mesmo antes de proferir sua fala, modela-a, considerando a imagem que cria de seu interlocutor. Nessa relaçăo dialógica, conforme Ohuschi (2013), existem atitudes responsivas de ambas as partes.

A partir do exposto, destaca-se a relevância do interlocutor no processo de interaçăo verbal, porque, da mesma forma que a situaçăo social, ele também define a enunciaçăo. Segundo Bakhtin/Volochinov (1992, p. 112), "a palavra dirige-se a um interlocutor" e, portanto, comporta duas faces: sempre procede de alguém e sempre se dirige a alguém, constituindo-se como produto da interaçâo do locutor e do ouvinte.

Há, de acordo com o Círculo de Bakhtin, três tipos de interlocutores: o interlocutor real, o representante médio do grupo social e a definiçấo de "terceiro", constante em "Marxismo e Filosofia da Linguagem", que é representado pelo horizonte social definido:

Mesmo que năo haja um interlocutor real, este pode ser substituído pelo representante médio do grupo social ao qual pertence o locutor [...] [a palavra] é funçâo da pessoa desse interlocutor: variará se se tratar de uma pessoa do mesmo grupo social ou náo, se esta for inferior ou superior na hierarquia social, se estiver ligada ao locutor por laços sociais mais ou menos estreitos. [...] Na maior parte dos casos, é preciso supor além disso um certo horizonte social definido e estabelecido que determina a criaçâo ideológica do grupo social e da época a que pertencemos, um horizonte contemporâneo da nossa literatura, da nossa ciência, da nossa moral, do nosso direito (BAKHTIN/ VOLOCHINOV, 1992, p. 112).

Em "Estética da criaçáo verbal" (BAKHTIN, 2003), além dos interlocutores citados, a noçâo de "terceiro", entendido como supradestinatário, superior, um interlocutor terceiro, idealizado, também está contemplada. $O$ enunciado tem sempre um destinatário "cuja compreensâo responsiva o autor da obra de discurso procura e antecipa. Ele é o segundo" (BAKHTIN, 2003, p. 332); no entanto, além dele, o autor do enunciado estabelece,

[...] com maior ou menor consciência, um supradestinatário superior (o terceiro), cuja compreensăo responsiva absolutamente justa ele pressupóe quer na distancia metafísica, quer no distante tempo histórico [...] Em diferentes épocas e sob diferentes concepçóes de mundo, esse supradestinatário e sua compreensăo responsiva idealmente verdadeira ganham diferentes expressóes ideológicas concretas (Deus, a verdade absoluta, o julgamento da consciência humana imparcial, o povo, o julgamento da história, etc.) (BAKHTIN, 2003, p. 333, grifos nossos).

O interlocutor terceiro consiste em uma instância que pode aparecer como um "enunciador impessoal", um modelo de uma comunidade a que o enunciador pertence ou deseja pertencer, um duplo enunciador, uma "forma-sujeito idealizada de uma formaçâo discursiva", um "objeto do enunciado", uma "voz da consciência", um "subdestinatário no "pequeno diálogo"'" (FURLANETTO, 2012, pp. 339-340).

Ao discutir questōes voltadas à escrita acadêmica, tratando especificamente da publicaçăo de artigos científicos em periódicos, é possível exemplificar, de forma geral, essa relaçăo da escrita com os tipos de interlocutores. 
O pesquisador-autor terá como seu interlocutor real o avaliador da revista, que irá mediar o processo de escrita para que o trabalho chegue à publicaçăo, realizando a correçâo e as intervençôes necessárias para uma possível readequaçăo do trabalho para publicaçấo. Todavia, ao escrever, o pesquisador-autor terá em mente seu público-alvo - as pessoas que leem periódicos científicos impressos ou digitais (interlocutores virtuais), ${ }^{120}$ pertencentes à sua esfera acadêmica, a partir dos quais adequará a linguagem e incluirá informaçóes apropriadas para sua compreensăo. Ao ter seu trabalho aceito ou publicado, o autor-pesquisador se reporta a uma ideologia dominante, a comunidade acadêmica, composta por estudiosos da área, pelos membros do periódico, pelas normas de submissâo e de avaliaçăo da revista (interlocutor terceiro) que determinam a conduta da escrita.

O interlocutor recebe e compreende o enunciado, seja ele escrito ou oral, tomando uma atitude responsiva que permanecesse em constante elaboraçăo durante o processo de compreensăo, já que, ao compreender o significado do discurso, o ouvinte adota uma "ativa posiçăo responsiva: concorda ou discorda dele (total ou parcialmente), completa-o, aplica-o, prepara-se para usá-lo, etc." (BAKHTIN, 2003, p. 271).

Quanto à questăo da responsividade, Menegassi (2009, p. 152) postula que năo se trata somente de uma resposta às práticas de linguagem ou da oferta de uma resposta ao locutor, mas sim da compreensăo de que a formulaçăo de um enunciado que se destina ao outro constitui uma resposta a diversos enunciados que circulam socialmente.

Bakhtin (2003) propóe três formas de compreensăo responsiva, a saber: ativa, passiva ou silenciosa - de efeito retardado. No primeiro caso, ao compreender o enunciado, o interlocutor responde imediatamente a ele, expondo sua opiniăo, seu julgamento de valor, concordando ou discordando etc. Já na compreensăo passiva, tem-se um elemento abstrato do fato real e, segundo Menegassi (2009, p. 163), a passividade da resposta está justamente "no fato de que a devolutiva ao enunciado formulado pelo locutor se manifesta, no outro, pelo atendimento e cumprimento de um pedido, uma solicitaçăo ou uma ordem". Há a compreensăo do enunciado pelo ouvinte, contudo temse uma "relaçấo social altamente assimétrica, autoritária na relaçâo entre falante e ouvinte, tanto que Bakhtin singulariza esse fato ao buscar o exemplo na ordem militar" (MENEGASSI, 2009, p. 163).

Quanto à compreensăo responsiva silenciosa ou de efeito retardado, o interlocutor traz uma resposta, contudo, em outro momento:

[...] a compreensăo ativamente responsiva do ouvido [...] pode realizar-se imediatamente na açăo [...], pode permanecer como compreensăo responsiva silenciosa, mas isto, por assim dizer, é uma compreensáo responsiva de efeito retardado: cedo ou tarde, o que foi ouvido e ativamente atendido responde nos discursos subsequentes ou no comportamento do ouvinte (BAKHTIN, 2003, pp. 271-272).

120 Autores como Garcez (1998) e Menegassi (2009) utilizam tal denominaçăo. Segundo Menegassi (2009, p. 156) quando o sujeito náo define um interlocutor imediato/real, o locutor "formula seus enunciados a partir de certa imagem de um interlocutor ideal ou virtual, uma espécie de representação genérica [...] constituído por características gerais de um suposto parceiro da enunciaçăo". Dessa forma, o interlocutor virtual seria aquele passível de existência. 
Constata-se que a compreensâo (ativa, passiva ou silenciosa) conduz o interlocutor a postular uma atitude responsiva que pode ser ativa, passiva ou silenciosa, pois os sujeitos aguardam uma resposta e nâo somente a repetiçăo de seus discursos (OHUSCHI, 2013).

No caso da produçăo científica de artigos nos periódicos, é possível traçar a questăo da responsividade no processo existente entre pesquisador-autor e normas de submissăo e normas dos avaliadores postuladas pela revista. Geralmente, ao pensar na publicaçáo para um periódico, o sujeito busca as normas de submissáo de seu texto, observando principalmente o que se espera quanto à forma composicional do gênero artigo, demonstrando, na maioria das vezes, uma resposta ativa ao que é esperado, expondo suas ideias dentro dos padróes estabelecidos. No entanto, caso o sujeito restrinja sua escrita apenas aos padróes formais estabelecidos pela revista, sem atentar para outros fatores envolvidos, como questôes éticas, temáticas, repetiçâo de ideias, evidencia-se uma atitude responsiva passiva, em que apenas cumpriu a atividade de adequar seu texto formalmente, mas sem observar questóes que influenciam diretamente em sua produçăo.

Alguns sujeitos podem apresentar uma responsividade em outro momento, em outro artigo que será publicado, em outra ocasiāo de escrita, mostrando que levou um tempo para internalizar aqueles conhecimentos, demarcando uma atitude responsiva silenciosa. A responsividade é marcada quando as palavras alheias - que nâo se restringem apenas às normas das revistas, mas ao emaranhado de elementos que podem influenciam na escrita, como questóes temática, éticas, dentre outras - tornam-se palavras próprias.

Nas relaçôes dialógicas, ocorre uma multiplicidade de consciências, ao contrário do que ocorre no universo monológico, no qual, segundo Bakhtin/Volochinov (1992) e, sobretudo, em Bakhtin (2002), ocorre a fusăo das vozes e verdades em uma verdade única, em uma consciência geral que promove, na maioria das vezes, a homogeneizaçâo da produçáo.

De acordo com Sanches (2009a), no dialogismo, ainda que o autor insira em seu enunciado as vozes de outros sujeitos, tomando-as como suas, é possível identificar nuances que perpassam tais palavras, uma vez que sempre que se utiliza uma palavra, ela é revestida com a compreensâo, com a avaliaçâo do outro, tornando-se bivocal. O fato de uma palavra já ter sido utilizada anteriormente, nâo se constituindo como original, nâo significa que o produtor apenas a copia, pois, o trabalho de criaçăo e de compreensão consistem em lidar com vozes, fazendo que o sujeito inscreva a sua própria voz (AMORIM, 2004).

O texto científico é compreendido, muitas vezes, como apenas monológico, tendo em vista, por exemplo, normas estabelecidas pela Associaçáo Brasileira de Normas Técnicas (ABNT), dentre outros manuais, que preconizam uma escrita neutra, desprovida de subjetividade, considerando que apenas o fato de se produzir o texto em terceira pessoa já se configura como uma forma de afastamento do pesquisador dos fatos que expressa. Na realidade, outros elementos podem caracterizar o discurso como heterogêneo e dialógico, como a escolha dos autores para citaçăo, a escolha da temática, dentre outros fatores, que levam o discurso científico a estar ancorado também no dialogismo, porque é constituído em funçăo de sua relação com outros, apesar 
de năo haver, na maioria das vezes, centros discursivos diversos. Tal postura possibilita dizer que o dialogismo constitui o texto, em maior ou menor grau, demonstrando que a presença do outro sempre se faz presente (AMORIM, 2004).

A respeito das relaçôes dialógicas, em sua dissertaçăo, Sanches (2009) buscou analisá-las em artigos científicos das áreas de saúde e de segurança do trabalho, realizando a sistematizaçấo de seis tipos de relaçóes, a saber: 1) marca de novidade; 2) confirmaçấo e concordância; 3) diálogo com o conhecimento científico consensual; 4) referenciaçấo bibliográfica com apagamento dos limites discursivos; 5) enunciados "colcha de retalhos"; 6) discordância em relaçâo a enunciados alheios. Neste trabalho, para a análise dos discursos dos artigos científicos, algumas dessas relaçóes dialógicas sâo contempladas, além de outras advindas dos dados coletados. Elas serâo explanadas e exemplificadas na seçăo de análise juntamente com exemplos a fim de ilustrá-las.

\section{METODOLOGIA DO ESTUDO}

Neste texto, a escrita acadêmica é abordada nos artigos científicos das diferentes áreas do conhecimento. Para a seleçáo do periódico e do artigo para a análise, alguns critérios foram utilizados: nota no Qualis A1; áreas do conhecimento; modalidade da contribuiçấo; tempo de existência da revista e ano da coleta dos dados.

Tendo em vista a busca pela compreensâo dos discursos envolvidos na prática da produçăo científica no país, foram selecionados, no ano de 2012, periódicos A1, pois refletem, de certa forma, aquilo que é esperado pelo universo acadêmico, em termos de excelência, haja vista os critérios estabelecidos pelo Qualis, como publicaçấo reconhecida na área, condizente com as normas da ABNT, apresentando conselho editorial com membro do país e do exterior etc. Em relaçâo ao número de periódicos do estrato A1, destaca-se o quadro 1:

Quadro 1 - Levantamento dos periódicos do estrato A1 segundo WEBQUALIS (2012)

\begin{tabular}{|c|c|c|}
\hline ÁREA & $\begin{array}{c}\text { TOTAL DE REVISTAS } \\
\text { BRASILEIRAS A1 }\end{array}$ & $\begin{array}{c}\text { TOTAL DE REVISTAS } \\
\text { ESTRANGEIRAS A1 }\end{array}$ \\
\hline CIÊNCIAS AGRÁRIAS & 00 & 449 \\
\hline CIÊNCIAS BIOLÓGICAS & 00 & 753 \\
\hline CIÊNCIAS DA SAÚDE & 2 & 642 \\
\hline CIÊNCIAS EXATAS E DA TERRA & 5 & 307 \\
\hline CIÊNCIAS HUMANAS & 72 & 178 \\
\hline CIÊNCIAS SOCIAIS APLICADAS & 26 & 899 \\
\hline ENGENHARIAS & 1 & 78 \\
\hline
\end{tabular}

Fonte: baseado em Fuza (2015, p. 118).

Diante do levantamento realizado, em todas as áreas de conhecimento 
investigadas, o número de revistas estrangeiras A1 é superior ao número de periódicos brasileiros. Em uma escala crescente de número de revistas brasileiras A1, observase que as Ciências Agrárias e Biológicas nâo possuem revista A1; as Engenharias têm uma; as Ciências da Saúde, duas; as Ciências Exatas e da Terra, cinco; as Ciências Sociais Aplicadas, vinte e seis; a área de Linguística, Letras e Artes, cinquenta e cinco; e, por fim, as Ciências Humanas possuem setenta e duas revistas.

Em funçâo da crença de que há múltiplas práticas envolvidas na produçâo da escrita, havendo variaçâo na produçáo dos discursos de uma área para outra, optou-se por selecionar artigos de periódicos de diferentes áreas do conhecimento. A escolha pelo artigo científico ocorreu em razâo de ser o gênero de maior recorrência nos periódicos e no contexto da academia, logo, carrega consigo marcas desse universo e dos sujeitos que os constituem.

Os sites de todas as revistas brasileiras A1 foram visitados. Isso possibilitou a escolha de um periódico representativo de cada área em funçăo do tempo de existência da revista, consagrado em seu campo acadêmico, fundadas, respectivamente, em 1929 (Área: Multidisciplinar; subárea: Engenharias), 1950 (Ciências Humanas; subárea: História), 1979 (Ciências Sociais Aplicadas; subárea: Serviço Social), 1983 (Linguística, Letras e Artes; subárea: Letras/Linguística), 1985 (Ciências Exatas; subárea: Ensino), 1993(Ciências da Saúde; subárea: Enfermagem). Os periódicos năo săo identificados pelos nomes, mas sim por suas áreas de conhecimento, já que tal dado nâo se faz relevante para o estudo.

A partir disso, foi realizada a busca de um artigo representativo no interior desses periódicos que apresentasse características gerais da área, além de certas singularidades, ou seja, elementos que os diferenciavam dentro da área, dando possibilidade de discussáo a respeito da heterogeneidade da escrita. Foram observados em cada site de periódico: dois periódicos do ano de 2012 (ano da coleta dos dados no Qualis) assim como dois exemplares do ano de 2013 (o número de artigos lidos é variável de revista para revista tendo em vista o número de textos publicados em cada exemplar das áreas).

De forma geral, o quadro 2 apresenta o número de artigos lidos para a possível seleçáo:

Quadro 2 - Levantamento dos artigos nas revistas para seleçăo do texto

\begin{tabular}{|c|c|}
\hline ÁREA & Número de artigos lidos para possível seleção \\
\hline CIÊNCIAS DA SAÚDE & 88 \\
\hline CIÊNCIAS EXATAS E DA TERRA & 64 \\
\hline CIÊNCIAS HUMANAS & 40 \\
\hline CIÊNCIAS SOCIAIS APLICADAS & 24 \\
\hline ENGENHARIAS & 10 \\
\hline LINGUÍSTICA, LETRAS E ARTES & 32 \\
\hline
\end{tabular}

Fonte: A autora.

Por meio desse levantamento geral, foi possível a seleçâo de um artigo de cada periódico e sua análise que passou pela descriçăo de sua forma composicional, temática e estilística. Todo o trabalho realizado permitiu verificar elementos que constituem heterogeneamente os textos de cada área, como as relaçôes dialógicas, analisadas na sequência. 


\section{RELAÇÕES DIALÓGICAS ESTABELECIDAS NO INTERIOR DOS ARTIGOS DAS DIFERENTES ÁREAS: BREVE ANÁLISE}

Ao analisar os artigos científicos, um dos elementos responsáveis por determinar a sua heterogeneidade é a relaçăo dialógica estabelecida no interior dos discursos dentro de cada área.

Na sequência, examinam-se as relaçōes dialógicas definidas após a análise dos discursos dos artigos, destacando-se exemplos. De forma geral, foram identificados sete tipos de relaçōes dialógicas ${ }^{121}$, a saber: diálogo com o conhecimento científico consensual; relaçăo de pergunta e resposta; concordância com discursos alheios; discordância dos discursos alheios; marca de novidade; inserçâo na comunidade científica; relaçáo de questionamento da teoria existente.

\section{DIÁLOGO COM O CONHECIMENTO CIENTÍFICO CONSENSUAL ${ }^{122}$}

Nesse tipo de relaçăo, as informaçôes săo evidenciadas no texto como um conhecimento consensual na comunidade acadêmica e uma verdade (SANCHES, 2009a). Essa verdade, conforme postula Bakhtin (2003), ocupa o lugar de interlocutor terceiro, ou seja, o conhecimento científico é posto como algo absoluto. Porém, esse terceiro é suposto pelo autor enquanto sujeito, năo podendo tomar a palavra, sendo a sua voz reproduzida enquanto bifurcaçâo, pois destinatário e interlocutor terceiro sâo instâncias que introduzem uma relaçâo de estranhamento entre locutor e seus próprios enunciados (AMORIM, 2004).

Segundo Amorim (2004), o interlocutor terceiro e o próprio destinatário exercem influência na organizaçăo da obra científica. A forma composicional do artigo e, no caso, do resumo com paragrafaçâo única, uso da impessoalidade, das seçōes definidas, como objetivos, metodologia, resultados etc., é reflexo do interlocutor terceiro, visto que "tais exigências săo consensuais e pressupostas pela comunidade científica enquanto regras para que se faça a argumentaçăo, constituindo uma especificidade do dialogismo científico" (SANCHES, 2009a, p. 147).

A análise dos artigos possibilitou constatar que a relaçăo de diálogo com o conhecimento científico consensual se apresentou em algumas seçōes dos artigos das diferentes áreas, conforme exposto no quadro 3.

121 Sanches (2009a) delimitou quatro delas: diálogo com o conhecimento científico consensual; concordância com discursos alheios; discordância dos discursos alheios; marca de novidade. A partir da análise dos artigos, este estudo constatou: relaçăo de pergunta e resposta; inserçăo na comunidade científica; relaçăo de questionamento da teoria existente.

122 O diálogo com o conhecimento científico consensual difere da relaçăo dialógica de inserçăo na comunidade científica, tendo em vista que a primeira é marcada por expressóes e elementos que tendem à generalizaçăo das teorias e dos discursos, năo havendo, por exemplo, mençâo aos autores evocados no texto (SANCHES, 2009a). A inserçăo, por sua vez, explicita a presença do outro teórico no texto por meio da especificaçáo de seus nomes, delimitando o sujeito enunciador e evidenciando que o discurso do artigo encontra-se inserido em um contexto maior de produçăo, perpassado por interlocutores terceiros. 
Quadro 3 - Relação de diálogo com o conhecimento científico consensual: seções dos artigos e áreas

\begin{tabular}{c|c} 
SEÇÃO DO ARTIGO & ÁREAS \\
\hline Resumo & Linguística; Sociais; Humanas; Exatas; Engenharias; Saúde. \\
\hline Introdução & Linguística; Sociais; Humanas. \\
\hline Metodologia & Engenharias. \\
\hline
\end{tabular}

Fonte: A autora

O diálogo com o conhecimento científico consensual está presente em algumas práticas recorrentes na escrita dos artigos: na busca-se de generalizaçấo de algum assunto, no uso de referências genéricas nos momentos de contextualizaçăo da pesquisa e na ausência de referências bibliográficas explícitas.

Quando no texto nâo há referências bibliográficas explícitas, demarca-se um consenso do trabalho com a comunidade científica a que pertence. Como exemplo, destaca-se o excerto do resumo da área de Ciências Sociais:

[...] o artigo tem por escopo reunir e comentar as salvaguardas jurídico- políticas disponíveis para o enfrentamento de tais questóes. Pretende-se, ainda, avaliar se este aparato jurídico-político, construído historicamente pelos assistentes sociais, é suficiente para melhor qualificar seu fazer profissional [...] (Ciências Sociais, p. 131, grifos nossos).

Nesse caso, além da ausência de referenciais teóricos, percebe-se que sáo destacadas, no momento em que săo apresentados os objetivos do estudo, as ideias de que já existem "salvaguardas jurídico-políticas disponíveis" e todo um "aparato construído historicamente pelos assistentes sociais". Săo informaçóes expostas como conhecidas e passíveis de discussăo pelo artigo, sendo colocadas como verdades aceitas.

Outro exemplo é trazido da área de Exatas, destacando-se o momento em que se detalha o aporte teórico que será utilizado, assim como estudos que envolvem o ensino de Matemática:

A formulaçăo e a aplicaçăo da pesquisa, bem como a análise dos resultados e as conclusôes foram baseadas no enfoque histórico-cultural de Vigotski e estudos sobre a linguagem matemática e a utilizaçáo da Leitura Escrita nas aulas de Matemática, de diversos pesquisadores (Ciências Exatas, p. 513, grifos nossos).

O resumo demarca um consenso científico năo pela mençăo da filiaçăo aos estudos de Vygotsky, mas justamente por trazer a ideia de que outros estudiosos também trabalham na busca por estudos envolvendo leitura e escrita nas aulas de matemática. Ao utilizar os termos "diversos pesquisadores", dá-se uma noçăo de generalizaçâo ao campo de pesquisa, já que năo se definem os autores - fato que possivelmente será determinado no desenvolvimento do artigo. Há o uso da generalizaçăo, indeterminando quem sâo os sujeitos pesquisadores, por meio do uso de expressâo generalizante "diversos".

A marca de generalizaçăo é bem recorrente quando se trata da relaçâo de consenso científico. Ela ocorre pelo uso do objeto de estudo como sujeito gramatical, bem como pela indeterminaçâo do sujeito, aliados ao uso de termos que levam à generalizaçăo. A linguagem empregada nos resumos, de forma geral, permite afirmar que todos estăo 
submersos nesta relaçăo de diálogo com o conhecimento científico consensual, haja vista que se apresentam por meio do uso da terceira pessoa do singular, da voz passiva, dando amplitude para o objeto que é estudado, apagamento a figura do sujeito pesquisador, conforme se exemplifica:

Este texto apresenta um dos tipos de respostas possíveis à pergunta [...] Examinamse críticas e alternativas a essas respostas, apoiadas pelo autor (Ciências Humanas, p. 17, grifos nossos).

[...] 0 artigo tem por escopo reunir e comentar [...] Pretende-se, ainda [...] (Ciências Sociais, p. 131, grifos nossos).

O corpus, [...], se compóe dos primeiros artigos publicados para divulgar resultados de pesquisas, realizadas no Brasil, sobre redaçôes de vestibular [...] (Linguística, p. 283, grifos nossos).

Há marcas evidentes que permitem a generalizaçăo e a consequente noçăo de que o estudo está em diálogo com o conhecimento científico consensual, năo se considerando a marcaçăo de pessoalidade, apagando-se a figura do sujeito, ao utilizar voz passiva, verbos com partícula apassivadora "se", verbos no infinitivo que năo permitem determinar a pessoa do discurso.

As introduçōes dos artigos das áreas de Sociais, Linguística e Humanas utilizam este tipo de relaçăo dialógica essencialmente no momento de contextualizar o assunto, fazendo uso de referências genéricas, conforme se destaca:

Muito se tem escrito sobre o conjunto de reformas econômicas e Ideopolíticas. Suas causas, seu receituário [...] foram e continuam sendo objeto de estudos e pesquisas por parte de intelectuais de diversas vertentes e áreas do conhecimento, de padrăo nacional e internacional, dispensando uma explanaçăo mais circunstanciada [do] tema (Sociais, p. 132, grifos nossos).

De certa forma, a área de Sociais apresenta a relaçăo dialógica com uma funçâo similar, como maneira de servir de pano de fundo para delimitaçóes futuras de estudiosos que focam nas reformas econômicas e ideopolíticas. Dá-se espaço para o leitor reconhecer o tema abordado no texto e para pesquisar em outras fontes a respeito do assunto, haja vista que há muito material já confeccionado. O leitor é um sujeito que deve se reconhecer como inserido dentro da comunidade e, por isso, detentor de conhecimentos suficientes para compreender aquilo que é discutido no texto. Outro exemplo que aponta o consenso com o conhecimento científico da área de Sociais é "estudos recentes têm revelado as intercorrências desastrosas das transformaçóes societárias no âmbito do Serviço Social" (p. 134). Nesse caso, há a referência genérica (CORACINI, 1991) que náo revela com precisăo a origem efetiva do pensamento, indefinindo parcialmente o autor citado. Isso descompromete o locutor com relaçầo à asserçăo, pois a transfere para outro genérico, no caso, "estudos recentes". 


\section{RELAÇÃO DE PERGUNTA E RESPOSTA}

Concebe-se a alteridade como um princípio estruturador das relaçóes dialógicas, haja vista que todo enunciado é constituído em funçăo de seu interlocutor. O outro é inserido no enunciado, havendo sempre enunciados alheios dentro dele.

A relaçâo dialógica de pergunta e resposta que pressupôe a alteridade no enunciado ocorre apenas no interior do resumo da área de Humanas, haja vista a temática e a forma de composiçăo do próprio artigo da área.

Diante da pergunta, o interlocutor indagado deve tomar uma atitude quanto ao que lê, já que, ao compreender o significado do discurso, o ouvinte adota uma "ativa posiçâo responsiva: concorda ou discorda dele (total ou parcialmente), completa-o, aplica-o, prepara-se para usá-lo, etc." (BAKHTIN, 2003, p. 271). No entanto, no próprio resumo, constata-se que quem responde ao enunciado é o próprio autor do texto, tornando-se um diálogo consigo mesmo, pressupondo que outros interlocutores terăo acesso ao texto:

\footnotetext{
Este texto apresenta um dos tipos de respostas possíveis à pergunta: o que explica os comportamentos e açóes dos seres humanos? Especificamente, abordam-se as respostas que partem de uma natureza humana determinante, seja ela genética, de outro modo natural, ou náo explicitamente explicada por fatores naturais. Examinam-se críticas e alternativas a essas respostas, apoiadas pelo autor (Ciências Humanas, p. 17, grifos nossos).
}

O artigo apresenta uma das respostas possíveis à pergunta, ou seja, aquela com foco na "natureza humana determinante" e isso é apoiado pelo autor, inserido em uma comunidade científica. No próprio artigo, determina-se o enfoque a ser adotado em funçăo do emprego do advérbio "especificamente", demarcando que existem outras respostas, mas que, no espaço daquela discussăo, o enfoque recai em uma única posiçấo.

A ideia de alteridade, de defesa de um ponto de vista e de determinaçấo de uma forma de responder à pergunta, perpassa o título do artigo, o seu resumo e toda a organizaçâo composicional do texto, já que as seçôes sâo definidas e vâo afunilando para a noçấo que se defende.

Tal postura tomada pela área de Humanas pode ser reforçada pelos pressupostos de Amorim (2004). Para a autora, uma das especificidades das Humanas é a condiçấo de bipolaridade que perpassa o texto, já que no decorrer do texto sáo abordadas duas perspectivas que explicam o agir humano e que săo excludentes: a natural e a histórica.

\section{CONCORDÂNCIA COM DISCURSOS ALHEIOS}

Conforme Sanches (2009a), a concordância é uma das relaçôes mais presentes nos artigos, principalmente nos resultados e nas discussōes. Para Bakhtin (2003), năo é possível interpretar as relaçôes dialógicas em termos simplificados e unilaterais, reduzindo-as a uma contradiçăo, luta, discussăo, haja vista que "a concordância é uma das formas mais importantes de relaçōes dialógicas" (BAKHTIN, 2003, p. 331).

A partir da análise dos artigos, pode-se constatar que a relaçâo de concordância se apresentou em algumas seçôes dos artigos das diferentes áreas, conforme exposto no quadro 4. 
Quadro 4 - Relação de concordância com discursos alheios: seções dos artigos e áreas

\begin{tabular}{|c|c|}
\hline Seção do artigo & Áreas \\
\hline Introdução & Linguística; Saúde; Sociais \\
\hline Fundamentação teórica e análise dos dados & Linguística \\
\hline Conclusão & Humanas; Exatas \\
\hline
\end{tabular}

Fonte: A autora.

A relaçăo de concordância com discursos alheios, presente em algumas seçóes dos artigos, revela os diálogos do texto com outros estudos já realizados, demarcando-se, muitas vezes, os elementos que sâo comuns a eles, como ocorre na área de Linguística: "Esses trabalhos, realizados segundo concepçôes teóricas distintas, apresentam em comum o fato de atribuírem a defasagem no desenvolvimento do ensino [...]" (Linguística, p. 284, grifos nossos). O pesquisador inicia sua introduçấo expondo a existência do interesse acadêmico pela produçáo escrita, de forma bastante genérica. Na sequência, aponta alguns trabalhos e estudiosos que apresentam estudos de análise de redaçóes escolares, como Val, Barros, dentre outros. Depois, explica (conforme se verifica no excerto) que, apesar de suas concepçōes teóricas distintas, eles "apresentam em comum" a ideia da defasagem do ensino da escrita às condiçôes de produçăo.

Quanto às áreas de Saúde e de Sociais, uma das formas de concordância presente na introduçăo, na fase da contextualizaçăo, é a marca de referenciaçăo a outros autores, já que o uso desse recurso é bastante forte nessas áreas. No caso da área da Saúde, em todos os parágrafos da introduçāo, há mençăo aos autores estudados, empregando-se a referência numérica, isto é, tudo aquilo que o pesquisador afirma está amparado em estudiosos:

A formaçấo profissional da enfermagem está dirigida para a importância de uma prática ética, buscando preparar os seus futuros trabalhadores a exercerem competentemente o enfrentamento cotidiano de problemas éticos e morais nos ambientes de trabalho, ou seja, o enfrentamento da incerteza moral, de dilemas morais e do sofrimento moral (1) (Saúde, p. 2, grifos nossos).

Ao mesmo tempo em que se pode afirmar que a existência dessas referências demarca uma relaçâo dialógica de inserçâo do sujeito na comunidade acadêmica que estuda tal temática, é possível dizer que há evidência de concordância entre discursos, haja vista que o pesquisador, em nenhum momento, retoma os estudos para se opor a eles ou para criticá-los, mas sim para dar credibilidade ao que afirma. De acordo com Sanches (2009a), as marcas de referenciaçāo bibliográfica podem levar ao apagamento dos limites entre os diferentes discursos, configurando-se como uma forma de tomada da palavra do outro para si, incorporando-o ao seu discurso, expressando confiabilidade, credibilidade ao texto.

A concordância ocorre no momento em que os autores fazem uso dos discursos de outros estudiosos para fundamentar teoricamente sua pesquisa e essa postura perpassa os artigos. Os pesquisadores, na maioria das vezes, afirmam algo e trazem outro estudioso para mostrar concordância entre as ideias expostas.

A área de Linguística apresenta, no momento da fundamentaçăo, marcadamente, a concordância com um de seus aportes teóricos: "A hipótese sobre a necessidade de 
delimitaçăo se fundamenta na noçăo de interdiscursividade tal como proposta por Maingueneau (1997; 2005)" (p. 285, grifos nossos). Nesse caso, concorda-se teoricamente com aquilo que o estudioso postula, tendo em vista a necessidade de o estudo tratar da constituiçăo da escrita escolar em funçăo da polêmica entre perspectiva moderna e tradicional do estudo da língua, abordando a interdiscursividade.

A seçăo de análise presente no artigo de Linguística é perpassada pela relaçăo de concordância com discursos alheios, uma vez que a forma de construçăo dos elos entre os artigos analisados pelo pesquisador promove isso. Em primeiro momento, o pesquisador destaca os artigos que utilizaram pressupostos da linguística apenas para analisarem as escritas escolares. A partir disso, afirma: "O mesmo posicionamento se encontra no estudo do parágrafo: Mamizuka (1977) atribui a causa [...] Os artigos de Pécora (1977) e de Rodrigues \& Freire (1977) apresentam organizaçăo textual-discursiva semelhante aos demais [...]" (p. 290, grifos nossos). As expressōes utilizadas "mesmo posicionamento" e "semelhante" denotam que há concordância entre os objetos analisados. $O$ pesquisador busca realizar tais aproximaçôes discursivas.

Na seçăo seguinte, o pesquisador destaca os artigos que se contrapóem à noçăo de incompetência linguística, defendendo que o conhecimento linguístico do vestibulando se encontra dentro da normalidade. A partir disso, pontuam-se os estudos que concordam com essa postura:

A esse outro também responde o texto de Osakabe (1977) [...] Os artigos analisados se contrapóem, portanto, a perspectivas que atribuem os problemas de redaçáo a desconhecimento linguístico, bem como a trabalhos que assumem perspectivas tradicionais de linguagem e, em funçáo dessa fundamentaçăo teórica, apresentam posiçóes arbitrárias em relaçâo aos usos linguísticos (Linguística, pp. 292-293, grifos nossos).

No excerto, há as marcas que evidenciam relaçóes de concordância dentro do texto, haja vista que os artigos analisados apresentam um consenso em relaçâo aos problemas de redaçấo, contrapondo-se às perspectivas que vinculam os problemas ao desconhecimento linguístico dos sujeitos. Tal discurso é que dá abertura, por exemplo, para a seçâo de resultados, afirmando-se que "parece haver uma unanimidade entre os artigos observados" (p. 293), ou seja, todos dialogam no mesmo sentido, apresentando concordância entre seus discursos.

\section{DISCORDÂNCIA DOS DISCURSOS ALHEIOS}

A relaçăo de discordância dos discursos alheios (SANCHES, 2009a) ou movimento dialógico de distanciamento (RODRIGUES, 2005) é a menos frequente dentro dos artigos, podendo ocorrer de duas formas: por meio da contestaçăo sutil de um método, nâo havendo oposiçôes drásticas aos enunciados anteriores, ou da ironia aos discursos já expressos. Para a autora, a baixa recorrência desse tipo de relaçâo se dá em virtude da busca da boa relaçấo entre os agentes da esfera acadêmica ou da manutençấo daquela que já possuem.

De certa forma, a análise dos artigos demarcou a ocorrência da discordância nas áreas de Humanas e Saúde, nos momentos da fundamentaçăo teórica (e análise) e da discussăo, havendo variaçóes entre as formas de utilizaçăo da relaçăo dialógica (quadro 5). 
Quadro 5 - Relação de discordância dos discursos alheios: seções dos artigos e áreas

\begin{tabular}{|c|c|}
\hline \multicolumn{1}{|c|}{ Seção do artigo } & Áreas \\
\hline Discussão & Saúde. \\
\hline Fundamentação teórica e análise dos dados & Humanas. \\
\hline
\end{tabular}

Fonte: A autora.

A fim de ilustrar tal relaçăo, destaca-se o caso da área da Saúde. Nela, na seçăo de discussăo, verifica-se a relaçăo de discordância. Trata-se da mesma forma destacada por Sanches (2009a): contestaçăo sutil de um estudo já realizado. O pesquisador aponta ser importante realizar reunióes com a equipe de enfermagem, haja vista que, nesses ambientes, o sofrimento moral foi percebido e afirma: "Diferentemente do estudo desenvolvido anteriormente com enfermeiros brasileiros (2), em que 70,2\% dos enfermeiros afirmaram realizar reuniôes com a equipe, percebeu-se que a frequência de ocorrência das reuniōes foi baixa [...]" (Saúde, p. 8, grifos nossos). Retoma-se outra pesquisa, usando-se a referência numérica, indicando certa discordância em relaçáo a ela: "diferentemente do estudo desenvolvido anteriormente", tendo em vista que o pesquisador chegou ao resultado de que as reuniōes săo relevantes para o processo de reconhecimento do sofrimento moral.

De certa forma, o artigo náo é totalmente oposto àquilo que já se estudou em relaçăo ao assunto, apenas mostra oposiçăo ao que foi realizado. Isso faz que se entenda realmente, como Sanches (2009a), que há a busca por manter uma boa relaçâo entre os agentes da esfera acadêmica, uma vez que, conforme já apontado, o artigo de Ciências da Saúde aborda, por meio de referências numéricas, diversos autores, demonstrando a preocupaçăo em manter o vínculo com aquilo que vem sendo desenvolvido dentro da comunidade científica.

\section{MARCA DE NOVIDADE}

A marca de novidade complementa estudos anteriores ao trazer novos dados. Os dados da pesquisa revelaram que essa relaçâo é uma das mais recorrentes nos textos.

Quadro 6 - Relação de marca de novidade: seções dos artigos e áreas

\begin{tabular}{|c|c|}
\hline Seção do artigo & Áreas \\
\hline Resumo & Sociais; Saúde; Humanas. \\
\hline Introdução & Sociais; Saúde; Engenharias; Humanas; Exatas; Linguística. \\
\hline Conclusão & Saúde; Sociais; Linguística. \\
\hline Metodologia & Exatas. \\
\hline
\end{tabular}

Fonte: A autora.

De acordo com Sanches (2009a), alguns aspectos configuram a novidade, como a marca de negaçâo que é um recurso amplamente utilizado para construir a noçâo de nova contribuiçấo à área do saber, e a própria justificativa do estudo. Outros pontos também podem possibilitar o movimento de novidade ao discurso, as expressóes utilizadas nos resumos dos textos, conforme exemplo: 
[...] Pretende-se, ainda, avaliar se este aparato jurídico-político [...] é suficiente para melhor qualificar seu fazer profissional [...], possibilitando a ampliaçáo do espaço ocupacional e condiçōes de trabalho e remuneraçăo adequadas (Sociais, p. 131, grifos nossos).

No exemplo, utiliza-se a marca de novidade justamente para demarcar uma contribuiçáo do estudo para a área: "possibilitando a ampliaçăo do espaço ocupacional e condiçôes de trabalho e remuneraçăo adequadas", tendo em vista que o objetivo do estudo é avaliar o aparato jurídico-político construído ao longo dos anos pelos assistentes sociais.

A marca de novidade é bastante recorrente na introduçăo dos artigos das áreas, principalmente nos momentos de contextualizaçâo, justificativa e contribuiçăo. No caso das Ciências Sociais, a novidade advém das transformaçôes nas condiçôes de exercício profissional do assistente social que é foco do trabalho, destacando-se as leis que dâo respaldo para isso:

Para atender aos fins deste artigo, basta assinalar que ditas transformaçōes [...] modificaram substancialmente náo só o paradigma do processo e gestăo do trabalho capitalista e o sistema estatal, mas, também [...] Por conseguinte, influenciam também as condiçóes do exercício profissional [...] O espaço ocupacional ampliouse também com atividades voltadas para implantaçăo, orientaçăo e representaçăo em Conselhos de Políticas Sociais e de Direitos (Sociais, p. 132, grifos nossos).

No caso das Ciências Sociais, fez-se um percurso das transformaçóes no padrăo social do trabalho, acrescentando-se a noçâo do exercício profissional e também as atividades voltadas para implantaçâo e orientaçáo nos Conselhos. Todo esse acréscimo de informaçōes, evidenciada pelas expressōes "năo só", "mas, também", "também", surge justamente para "atender aos fins" do artigo, conforme está marcado no excerto. De certa forma, a busca por demarcar o acréscimo de informaçăo dentro da contextualizaçâo é justamente para propor que há, sim, visōes já existentes em relaçăo à temática e que o artigo procura evidenciar mais um foco, como ocorre na área da Saúde:

Ao se refletir sobre o SM e os problemas da profissăo, lida-se com algo maior do que uma análise de como as relaçôes de poder se constroem e se desconstroem na enfermagem e na saúde, avançando-se para o modo como os profissionais da enfermagem se transformam em sujeitos, se subjetivam e se constroem como seres éticos (Saúde, p. 3, grifos nossos).

As expressōes utilizadas mostram a relaçăo de diálogo entre estudos com foco na "análise de como as relaçóes de poder se constroem e se desconstroem na enfermagem e na saúde", indo além dessa perspectiva, visto que o estudo "avança" para a noçâo de como os profissionais da enfermagem "se transformam em sujeitos, se subjetivam e se constroem como seres éticos, percebendo o SM e enfrentando, ou năo, os problemas morais a ele relacionados".

As áreas que apresentam marcas de novidade na conclusăo săo Saúde, Sociais e Linguística.

O artigo da área da Saúde apresenta, em sua conclusăo, dois grandes momentos de novidade. $O$ primeiro deles aborda os resultados finais do estudo, afirmando-se que "compreender o SM permite ir além do enfrentamento dos problemas morais dos próprios trabalhadores, chegando a configurar, de maneira mais ampla e reflexiva, a 
situaçăo da própria instituiçăo e do sistema de saúde" (Saúde, p. 8, grifos nossos). A novidade maior da pesquisa, entâo, é justamente "ir além" dos trabalhos que já sâo realizados e que postulam a necessidade do enfrentamento dos problemas morais. Para o pesquisador, ao entender o sofrimento moral, pode-se "chegar" à situaçấo da própria instituiçâao e do sistema de saúde. Isso é afirmado, pois a instituiçăo e o sistema de saúde "podem estar dificultando os cuidados de enfermagem e a atençáo integral na saúde, provocando, consequentemente, a necessidade da elaboraçáo de uma ética de sujeitos ativos e de amplas possibilidades, definidas principalmente pelas relaçóes consigo mesmos" (Saúde, p. 8, grifos nossos).

Há a influência da instituiçăo e do sistema de saúde no sofrimento moral e, a partir disso, demarca-se um dos pontos de novidade do estudo: "a necessidade da elaboraçâo de uma ética [...] consigo mesmos". A questăo da ética é mencionada e principalmente na área da Saúde, ela é destacada, tendo em vista que trata do contato e da relaçáo entre os sujeitos. $O$ artigo tende a sugerir a importância das relaçóes dos sujeitos consigo mesmos, dialogando em busca de respostas para o sofrimento moral que os assola. Talvez seja por esse motivo que o pesquisador opta por demarcar, principalmente na introduçăo, que se busca refletir avançando para o modo como os profissionais se transformam em sujeitos, fazendo referências aos textos de Foucault.

A partir dessas constataçóes, o pesquisador traz seu segundo momento de novidade para o texto, destacando a contribuiçăo de seu estudo para a temática:

Nessa perspectiva, parece ser uma alternativa eficaz aos profissionais de enfermagem questionarem-se, estranharem os fatos diários, problematizando o cotidiano e as relaçôes instituídas, buscando [...] formas de desnaturalizar práticas previamente estabelecidas e comumente aceitas (Saúde, p. 8, grifos nossos).

O artigo parece lançar ao profissional de enfermagem a responsabilidade por identificar e por entender como ultrapassar o sofrimento moral ocasionado por situaçóes cotidianas do ambiente de trabalho. Busca-se fazer que, além de se abordarem as instituiçōes, questionando-se seus papéis, é preciso que os profissionais, concebidos como sujeitos, questionem-se, estranhem seus afazeres cotidianos como forma de atuarem nas situaçôes e de năo estarem assujeitados a elas.

\section{INSERÇÃO NA COMUNIDADE CIENTÍFICA}

A marca de inserçăo na comunidade científica é bastante evidente no decorrer dos artigos científicos das áreas estudadas. No entanto, apenas três áreas apresentam a preocupaçăo em inserir o estudo em um aporte teórico definido, desde o resumo, a saber: Ciências Humanas, Linguística, Letras e Artes, Ciências Exatas.

Para que haja a produçâo científica e a circulaçăo do conhecimento, o estudo tem a necessidade de estar inserido em um contexto maior de produçâo da ciência, ou seja, em uma comunidade acadêmica. As vozes e as marcaçôes de autores, de correntes teóricas e de aporte teórico sâo expostas como formas de dar credibilidade ao texto apresentado, havendo o uso do discurso citado, da mençấo ao autor que pode marcar um consenso latente dentro da esfera. 
Quadro 7 - Relação de inserção na comunidade científica: seções dos artigos e áreas

\begin{tabular}{|c|c|}
\hline Seção do artigo & Áreas \\
\hline Resumo & Humanas; Linguística; Exatas. \\
\hline Introdução & Exatas; Sociais; Engenharia; Saúde; Humanas. \\
\hline Fundamentação teórica & Humanas; Linguística; Sociais. \\
\hline Metodologia & Saúde; Exatas. \\
\hline
\end{tabular}

Fonte: A autora.

As áreas de Ciências Exatas e Linguística demarcam claramente a ancoragem em uma filiaçâo teórica:

A formulaçăo e a aplicaçăo da pesquisa, bem como a análise dos resultados e as conclusóes foram baseadas no enfoque histórico-cultural de Vigotski e estudos sobre a linguagem matemática e a utilizaçăo da Leitura Escrita nas aulas de Matemática, de diversos pesquisadores (Ciências Exatas, p. 513, grifos nossos).

O corpus, analisado segundo perspectiva discursiva de linha francesa, se compóe dos primeiros artigos publicados para divulgar resultados de pesquisas, realizadas no Brasil, sobre redaçōes de vestibular (Linguística, Letras e Artes, p. 283, grifos nossos).

Existem marcadores de referência, como "baseado em", "segundo", que retomam o conhecimento da comunidade para mostrar inserçăo do sujeito dentro do contexto maior de pesquisa. Evidenciar a corrente ou o estudioso em que o estudo se ancora constitui uma estratégia a favor da credibilidade e do conceito de cientificidade (CORACINI, 1991).

No caso das Ciências Humanas, alternativas e críticas para as possíveis respostas ao título do artigo serăo "apoiadas pelo autor", conforme já mencionado, evidenciando que ele se encontra dentro de uma comunidade maior que apresenta outras posturas, mas que possibilita a ele delimitar apenas umas das respostas possíveis: "Especificamente, abordam-se as respostas que partem de uma natureza humana determinante [...]".

As introduçóes dos artigos de Exatas, Sociais, Engenharia, Saúde e Humanas apresentam marcas de inserçâo dos trabalhos na comunidade científica, isto é, indicam que estâo inseridos em uma esfera maior que delimita a realizaçăo do estudo, a escolha da temática etc. Ao analisar os artigos, a relaçâo de inserçăo na comunidade científica denota alguns valores. No caso do artigo de Ciências Exatas, tem-se marca de inserçâo no:

\footnotetext{
[...] embasamento teórico da formulaçăo, da aplicaçăo e do acompanhamento da pesquisa, bem como da análise dos resultados e das conclusóes, foi feito à luz do enfoque histórico-cultural de Vigotski $(1998,2001)$, da mesma forma que de estudos realizados recentemente sobre a linguagem matemática e a utilizaçáo da Leitura e Escrita nas aulas de Matemática, por diversos pesquisadores, como Corrêa (2005), Fonseca e Cardoso (2005), Malta (2004), Mesquita (2001), Pimm (1999), Santos (2005) e Smole e Diniz (2001) (Exatas, p. 514-515, grifos nossos).
}

Ao contrário da relaçăo dialógica de conhecimento científico consensual, que năo aponta explicitamente os autores usados (por exemplo, fazendo uso de referências genéricas, pressupondo que o leitor conheça o assunto), no caso da inserçăo na comunidade científica, existem evidências explícitas de que há vínculo entre a individualidade do trabalho e o todo que envolve sua produçăo. 
No caso das Exatas, a inserçăo está marcada no momento de enunciar o aporte metodológico do estudo: "enfoque histórico-cultural de Vigotski"; ao invés de expor genericamente que "diversos pesquisadores" fazem estudo da temática abordada no artigo, há a ampliaçăo e a especificaçâo disso ao usar a citaçăo dos estudiosos que se voltam para a perspectiva seguida pelo pesquisador: "Corrêa (2005), Fonseca e Cardoso (2005), Malta (2004) [...]". Em razâo de o espaço na introduçâo ser bastante breve, no caso das Exatas, a inserçāo se dá apenas para indicar o embasamento teórico, havendo a explanaçâo e a retomada dos autores mencionados no decorrer do artigo.

Já na área de Engenharias, a relaçâo dialógica de inserçăo está presente em alguns parágrafos da introduçâo, nos momentos em que se tem o histórico sobre a Barragem de Orós, foco do estudo:

Desde o tempo do império brasileiro, a barragem de Orós foi uma fonte de reflexóes. Somente no período republicano, nos primeiros anos da Inspeçăo Federal de Obras Contra a Seca, fundado em 1909, foi estudado e concluído o projeto da barragem, destruído por um incêndio em $1912^{123}$ [...] (Engenharias, p. 406, traduçăo nossa).

Boch (2013) concebe o quadro histórico como uma forma de indexar o objeto do estudo às correntes ou a outros autores que abordam o assunto, como "Araújo, 1990", citado ao longo do artigo. A marca de historicidade é evidenciada essencialmente pelo uso de verbos no pretérito, como "foi", "foi estudado e concluído". A área de Humanas faz uso da relaçăo de inserçăo justamente ao evidenciar o recorte de uma perspectiva em funçăo de haver outras existentes:

[...] só desenvolverei uma das modalidades possíveis de respostas à pergunta contida no título, isto é, as concepçōes que atribuem os comportamentos humanos ao impacto de uma natureza humana, bem como as críticas a elas. Ficarăo de fora quase inteiramente, entăo, múltiplos elementos que apareceriam se fossem discutidas posturas de outros tipos, por exemplo, 0 impacto das ideologias, representaçóes coletivas e programaçóes sociais do comportamento sobre as açóes humanas (Humanas, p. 19, grifos nossos).

O próprio autor é responsável por indicar que apenas uma modalidade de tratamento da temática será abordada "uma das modalidades possíveis de respostas à pergunta". No entanto, náo deixa de mencionar outros elementos que poderiam ser discutidos, como "o impacto das ideologias", fato que evidencia e situa o trabalho em um universo acadêmico que estuda a temática.

Ao tratar da inserçâo na comunidade científica na fundamentaçâo teórica sâo destacadas três áreas: Humanas, Linguística e Sociais, já que seus artigos apresentam, especificamente, uma seçăo destinada à exposiçăo de teorias. ${ }^{124}$ As outras áreas também apresentam suas teorias, no entanto embutidas em outras seçóes, como na introduçăo.

123 "Since the time of the Brazilian empire, the dam Orós was a source of reflections. Only in the Republican period, in the early years of the Federal Inspectorate for Works Against Drought, established in 1909, it was studied and completed the draft of the dam, destroyed by fire in 1912 [...]" (Engenharias, p. 406).

124 As outrasáreas de conhecimento citam a utilizaçăo de teóricos, seja na introduçăo, seja no desenvolvimento do estudo, fazendo uso de recursos de referências parecidos com os apresentados pelas áreas mencionadas. No entanto, este estudo, a fim de se referir à inserçăo na comunidade científica presente na seçáo de fundamentaçăo, opta pelos artigos que destinam um espaço específico para abordá-la. 
É possível afirmar que o momento de retomada teórica nos artigos analisados se configura como forma de inserção em uma comunidade maior de estudo, haja vista que a seção de fundamentação teórica tem a função de utilizar, de reconhecer e de dar crédito à criação intelectual de outro autor. Trata-se, então, de "uma questão básica de ética acadêmica e de consciência sobre o grau de ineditismo da nossa pesquisa, pois demonstramos saber que não estamos "reinventando a roda"' (MOTTA-ROTH; HEDGES, 2010, p. 90).

No caso da Linguística, a seçâo de fundamentaçăo é bastante breve, tendo como foco maior situar o trabalho dentro de uma área específica, "segundo perspectiva discursiva de linha francesa" (p. 284). O autor destaca os dois estudiosos que nortearăo o seu estudo, a saber, "Foucault e Maingueneau" (p. 284), demonstrando a concordância do pesquisador com as ideias expostas pelos teóricos: "[...] em acordo com a perspectiva foucaultiana, nâo se trata de procurar uma origem a partir da qual um processo contínuo levou à construçăo gradual de um novo objeto de estudos na área em questâo [...]"; "Segundo o autor [Maingueneau], a interdiscursividade [...]" (Linguística, p. 285, grifos nossos).

O discurso relatado é marcado pelas referências nominais aos autores, que săo antecedidas de expressóes como "em acordo com; segundo o autor". O pesquisador, a fim de utilizar a palavra do outro, realiza todo um trabalho de reformulaçâo interior, de síntese das informaçóes, transformando o dizer do outro, colocando-o a serviço do próprio objetivo, da nova situaçăo de interaçăo (CORACINI, 1991). Isso é evidente, principalmente, na paráfrase da teoria da "interdiscursividade" apresentada pelo pesquisador, com base em Maingueneau, porque se escolhe um dos assuntos estudados pelo autor e que serve de fundamento para o estudo da constituiçáo discursiva sobre as redaçôes escolares. No caso analisado, ao situar a pesquisa na fundamentaçăo teórica, sinaliza-se qual parcela da grande área é mais diretamente relevante para o estudo. Dentro da linha de estudo da análise do discurso de linha francesa, foca-se na interdiscursividade, na constituiçấo do discurso no decorrer do tempo. A relaçăo de inserçâo presente na metodologia das áreas de Saúde e Exatas ressalta o diálogo estabelecido entre pesquisador e estudiosos, pensando-se nas formas de organizar o desenvolvimento da pesquisa.

A área da Saúde, ao indicar como as questōes do questionário seriam analisadas, validou-as em constructos extraídos de outros estudiosos, conforme se verifica pelas referências numéricas que sâo colocadas logo após suas indicaçōes:

As vinte e três questóes do instrumento foram validadas em cinco constructos, denominados nesta pesquisa como: falta de competência na equipe de trabalho, definido como ausência de habilidade ou competência técnica [...] (11); negaçáo do papel da enfermagem como advogada do paciente, definido como o potencial năo utilizado pela enfermagem para reivindicar os direitos dos pacientes (17) [...] (Saúde, p. 4, grifos do autor e nossos).

Os numerais em negrito se referem aos autores utilizados e que serviram de fundamento para o estudo. Esse procedimento revela o consenso do autor com os teóricos estudados, isto é, toma-se a palavra do outro, torna-a sua, tendo em vista o estudo a ser realizado. A marca de diálogo entre os autores se dá pela numeraçấo, năo há indicaçâo do nome dos teóricos no texto, verbos que indicam citaçăo etc.

Outro elemento que caracteriza a inserçăo do trabalho em um contexto maior de produçăo científica é o fato de mencionar o papel do "Comitê de Ética em Pesquisa". Ao 
fechar a metodologia, o pesquisador informa ao leitor: "O projeto foi antecipadamente julgado e aprovado pelo Comitê de Ética em Pesquisa, com Parecer n. ${ }^{\circ}$ 70/2010" (Saúde, p. 4, grifos nossos). Esse dado responde diretamente àquilo que as normas de avaliaçăo dos pareceristas de alguns periódicos postulam (FUZA, 2015): o trabalho "respeita legislaçăo para pesquisa envolvendo seres humanos", indicando que ele pode estar inserido no contexto acadêmico, já que pesquisas envolvendo seres humanos devem passar pela aprovaçấo do Comitê, gerando-se um parecer, conforme consta: “Parecer n. ${ }^{\circ}$ 70/2010".

\section{RELAÇÃO DE QUESTIONAMENTO DA TEORIA EXISTENTE}

Essa relaçăo se volta para o questionamento presente no resumo quanto às teorias existentes e que o estudo busca analisar, funcionando como uma forma de testar o que já é corrente na área e o que pode ser ampliado por meio do estudo. Duas áreas utilizam tal relaçâo, a saber: Ciências Sociais e Engenharias.

O resumo de Ciências Sociais comenta as salvaguardas jurídico-políticas disponíveis e avalia o aparato existente, construído historicamente pelos assistentes sociais, verificando se o aparato "é suficiente para melhor qualificar seu fazer profissional e contrapor-se aos níveis de desemprego e precariedade do trabalho". A forma de construçấo da sentença demarca uma noçáo de questionamento daquilo que já se tem, buscando evidenciar se o aparato é suficiente para que se possam qualificar os profissionais.

Com essa mesma perspectiva, tem-se a ideia presente no resumo das Engenharias, que objetiva apresentar a aplicaçâo prática de conceitos e alguns métodos de análise de risco, para verificar a possibilidade de superaçâo da lâmina d"água de projeto no vertedouro da barragem Orós, pelo excesso de vazăo afluente. Para que isso aconteça, o artigo buscou avaliar "as fórmulas empíricas do projeto original", ou seja, partiu-se de algo já existente, questionando-se a teoria apresentada, a fim de que novas possibilidades de estudos fossem geradas.

\section{RESULTADOS E DISCUSSÕES}

A análise possibilitou delimitar sete tipos de relaçōes dialógicas nos artigos científicos das áreas do conhecimento. As relaçōes encontradas e as áreas dos artigos nas quais ocorrem sâo destacadas na sequência:

Quadro 8 - Relações dialógicas estabelecidas no interior dos artigos científicos das áreas

\begin{tabular}{|c|c|}
\hline RELAÇÕES DIALÓGICAS & ÁREAS \\
\hline $\begin{array}{c}\text { DIÁLOGO COM CONHECIMENTO CIENTÍFICO } \\
\text { CONSENSUAL }\end{array}$ & $\begin{array}{c}\text { Sociais; Exatas; Engenharias; Humanas; Linguística; } \\
\text { Saúde. }\end{array}$ \\
\hline RELAÇÃO DE PERGUNTA E DE RESPOSTA & Humanas \\
\hline CONCORDÂNCIA COM ENUNCIADOS ALHEIOS & Linguística; Humanas; Saúde; Sociais; Exatas. \\
\hline DISCORDÂNCIA DOS DISCURSOS ALHEIOS & Humanas; Saúde. \\
\hline
\end{tabular}




\begin{tabular}{|c|c|}
\hline MARCA DE NOVIDADE & $\begin{array}{c}\text { Sociais; Saúde; Humanas; Engenharias; Exatas; } \\
\text { Linguística. }\end{array}$ \\
\hline INSERÇÃO NA COMUNIDADE CIENTÍFICA & $\begin{array}{c}\text { Humanas; Linguística; Exatas; Sociais; Engenharias; } \\
\text { Saúde. }\end{array}$ \\
\hline RELAÇÃO DE QUESTIONAMENTO DA TEORIA & \begin{tabular}{c} 
Sociais; Engenharias. \\
\hline
\end{tabular} \\
\hline
\end{tabular}

Fonte: Fuza, 2015, p. 323.

Diante do exposto, verifica-se que as relaçóes dialógicas mais recorrentes nos artigos das áreas e que estăo presentes em todos eles săo a inserçăo na comunidade científica, o diálogo com conhecimento científico consensual e a marca de novidade. Embora sejam áreas específicas de conhecimento, as relaçōes dialógicas mostram-se semelhantes, tendo em vista o objetivo maior do gênero artigo científico: reportar um estudo, fazer o conhecimento circular, causando impacto na área de conhecimento.

O leitor do artigo precisa estar convencido de que o estudo realizado tem relevância para a área de saber em que a pesquisa se inscreve, logo há a busca incessante para inserir o trabalho no contexto de produçăo da comunidade científica, por meio da menção aos teóricos, às pesquisas já elaboradas, mesmo que seja de forma genérica, como ocorre no diálogo com conhecimento consensual. Além da necessidade de se enquadrar dentro de uma esfera maior acadêmica, respondendo às suas necessidades, o texto deve apresentar algo inédito, que seja relevante para o periódico e, consequente, que atraia a atençâo dos possíveis leitores da área.

Ao tratar da inserçâo do texto na comunidade científica, é possível afirmar que vários recursos, tanto linguísticos quanto discursivos, podem ser utilizados para delimitar essa relaçấo: uso de referências nominais, elemento mais utilizado como forma de evidenciar os teóricos e as pesquisas que vêm sendo produzidas na área, fazendo que o texto se insira na comunidade de produçăo da ciência; uso de notas de rodapé para especificar alguma informaçăo extra sobre o estudo ou para evidenciar a referência na íntegra; uso de referências numéricas que levam à mistura dos discursos do pesquisador e do teórico consultado sem se definir quem é o dono da palavra. De acordo com Coracini (1991), o uso e a profusâo de notas, de referências e de citaçôes constituem uma estratégia a favor da credibilidade e do conceito de cientificidade. A intençâo no uso dos discursos relatados parece ser "mostrar a importância e a pertinência da própria experiência, situá-la no conjunto de pesquisas da mesma área, enfim, conseguir adesăo do outro (leitor-cientista) à própria tese" (CORACINI, 1991, p. 170).

O uso das referências bibliográficas, ao final dos artigos, pode indicar inserçáo do estudo na comunidade científica, tendo em vista que se espera que a teoria mencionada seja adequada à temática abordada. De acordo com Coracini (op. cit.), caso algumas referências tidas como fundamentais no âmbito da especificidade năo se encontrem no texto, o leitor poderá concluir que o pesquisador năo está informado e que "suas palavras săo pouco dignas de crédito" (p. 170). Da mesma forma, um número limitado de citaçôes pode levar a concluir que o pesquisador nâo conhece as fontes de informaçăo que a comunidade científica considera como relevantes, "dados estes que seriam indispensáveis para a valorizaçăo do seu texto e, consequentemente, força persuasiva" (p. 170). A questăo da referência aos estudos da área atua como elemento que insere o texto em um contexto maior da ciência, atribuindo a ele credibilidade àquilo que é lido. 
As relaçóes de discordância dos discursos alheios e de relaçăo de pergunta e resposta sâo as menos utilizadas. No caso da discordância, a justificativa para o pouco uso pode advir do fato de que se deve estabelecer boa relaçăo entre os agentes da esfera acadêmica, mantendo o diálogo amigável entre os autores. Busca-se somente realizar contestaçôes sutis de algumas ideias, conforme observado nas análises. O fato de nâo haver tanta discordância nos textos justifica também a baixa recorrência da relaçăo de questionamento da teoria, realizada somente pelas áreas de Sociais e de Engenharias, haja vista que a busca está em evidenciar o que se tem na acadêmica e trazer algo inédito para complementar os estudos existentes.

A área de Humanas, por exemplo, faz uso da discordância, pela própria característica do estudo que traz diálogos entre teorias que abordam a natureza humana, a partir de duas perspectivas: natural e social. Em razáo disso, ao mesmo tempo em que discorda, o pesquisador concorda, fazendo uso da relaçáo de concordância com enunciados alheios.

A busca, entâo, para que o estudo esteja de acordo com aquilo que postula a esfera científica leva à segunda relaçáo dialógica mais recorrente: a de concordância com os discursos. Ao mesmo tempo em que o pesquisador se insere em um universo de pesquisa e discute teorias, ele as confirma, colocando-as em diálogo com seu pensar e com outros sujeitos que tratam da mesma temática.

A relaçâo de pergunta e de resposta ocorre apenas na área de Humanas, haja vista que o próprio texto é construído da relaçăo dúbia de perguntar e responder, visando à alteridade dos discursos que se faz tăo marcada no decorrer de todo o texto. Conforme Souza e Albuquerque (2012), a compreensâo dos temas que se quer investigar em pesquisas de Ciências Humanas ocorre pelos confrontos de ideias e negociaçáo de sentidos possíveis entre o pesquisador, as teorias etc. A alternância de perguntas e respostas fazem da pesquisa um processo vivo de produçâo de sentidos sobre os modos de perceber a natureza humana, pois o pesquisador năo apenas pergunta para obter respostas para os objetivos traçados no início do texto, mas, ao perguntar e também responder, "posiciona-se como um sujeito que do lugar de pesquisador traz perspectivas e valores diversos" (SOUZA; ALBUQUERQUE, 2012,308), tanto que, em vários momentos do texto, coloca-se como "eu" do discurso.

\section{CONSIDERAÇÕES FINAIS}

Este texto objetivou analisar as relaçôes dialógicas estabelecidas no interior dos discursos acadêmico-científicos presentes em artigos de periódicos nacionais A1 das diferentes áreas do conhecimento - Ciências Humanas, Ciências Exatas e da Terra, Ciências da Saúde, Ciências Sociais, Engenharias, Linguística, Letras e Artes. Dessa forma, dois objetivos foram delineados: a) destacar os tipos de relaçôes dialógicas presentes nos discursos das diferentes áreas; b) evidenciar a dialogicidade do discurso científico, marcado pela heterogeneidade discursiva.

Quanto ao primeiro, as análises dos artigos possibilitaram a constataçâo de sete tipos de relaçôes dialógicas no interior dos discursos em todas as áreas. Com isso, 
repensa-se a noçâo bakhtiniana, retomada por Amorim (2004), de que as Ciências Humanas aparentam mais dialogicidade, enquanto as Ciências Naturais săo consideradas como formas monológicas de conhecimento, visto que abordam objetos do mundo (terra, ar, pedras etc.).

A análise, de certo modo, reforça a noçăo de que todo discurso é dialógico por natureza, envolvendo um concerto de vozes, que podem ser dissonantes. Ao abordar o monologismo, o que ocorre, na realidade, é a intençăo de que o discurso se torne monológico, quando, na realidade, isso é uma ilusâo. Para Sobral (2009), há discursos que na superfície se organizam em termos monológicos, mas que, na verdade, săo dialógicos, como ocorre com o discurso acadêmico, já que cultua certas afirmaçôes, dando a impressăo de abafar a voz do outro, mas que, em seu âmbito, reconhece a presença de outros discursos no próprio ato de afirmar: "recordemos que negar é reconhecer uma dada afirmaçăo!" (SOBRAL, 2009, p. 39).

Ao considerar as relaçôes dialógicas, é possível ainda vincular algumas delas a motivaçôes maiores, em funçâo dos critérios dos pareceres dos avaliadores dos periódicos, constataçấo que poderá ser apresentada em outra oportunidade. 


\section{REFERÊNCIAS}

AMORIM, M. O pesquisador e seu outro: Bakhtin nas Ciências Humanas. Săo Paulo: Musa, 2004.

BAKHTIN, M. Problemas da poética de Dostoiévski. Traduçăo: Paulo Bezerra. 3. ed. Rio de Janeiro: Forense Universitária, 2002.

. Estética da criaçăo verbal. 4. ed. Sáo Paulo: Martins Fontes, 2003.

; VOLOCHINOV, V. N. Marxismo e filosofia da linguagem. 2. ed. Săo Paulo: Hucitec, 1992.

$\mathrm{BOCH}, \mathrm{F}$. Former les doctorants à l"écriture de la thèse em exploitant les études descriptives de l"écrit scientifique. Linguagem em (Dis)curso. Tubarăo (SC), v. 13, pp. 543-568, set.-dez. 2013.

CORACINI, M. J. Um fazer persuasivo: o discurso subjetivo da ciência. Săo Paulo: Educ; Campinas: Pontes, 1991.

CORTES, G. R. O. Dialogismo e Alteridade no Discurso Científico. Eutomia, Ano 2, n. 2, pp. 1-11., dez. 2009. Disponível em: <www.revistaeutomia.com.br/.../Dialogismo_e_ Alteridade_no_Discurso>. Acesso em: 10 jun. 2014.

FURLANETTO, M. M. Hiperenunciador: o outro do supradestinatário? Linguagem em (Dis)curso. Tubarăov. 12, n. 1, pp. 325-345, jan.-abr. 2012. Disponível em: < http://www3. unisul.br/paginas/ensino/pos/linguagem/1201/00.htm>. Acesso em: 20 jul. 2012.

FUZA, A. F. A constituiçáo dos discursos escritos em práticas de letramento acadêmico-científicas. 2015. 368 f. Tese (Doutorado em Linguística Aplicada)Instituto de Estudos da Linguagem, Universidade Estadual de Campinas, Campinas, 2015.

GARCEZ, L. H. C. A escrita e o outro: os modos de participaçăo na construçăo do texto. Brasília: UNB, 1998.

MENEGASSI, R. J. Aspectos da responsividade na interaçăo verbal, Línguas \& Letras, Cascavel, v. 10, n. 18. 2009. Disponível em: <http://erevista.unioeste.br/index.php/linguaseletras/article/view/2257/1750>. Acesso em: 15 jan. 2013.

MOTTA-ROTH, D.; HENDGES, G. H. Produçáo textual na universidade. Sáo Paulo: Parábola, 2010.

OHUSCHI, M. C. G. Ressignificaçăo de saberes na formaçăo continuada: a responsividade docente no estudo das marcas linguístico-enunciativas dos gêneros notícia e reportagem. 2013. 296 f. Tese. (Doutorado em Estudos da Linguagem) - Centro de Letras e Ciências Humanas, Universidade Estadual de Londrina, Londrina, 2013.

RODRIGUES, R. H. Os gêneros do discurso na perspectiva dialógica da linguagem: a abordagem de Bakhtin. In: MEURER, J. L.; BONINI, A.; MOTTA-ROTH, D. Gêneros teorias, métodos, debates. Sāo Paulo: Parábola Editorial, 2005, pp. 152-183.

SANCHES, K. P. Relaçóes dialógicas em artigos científicos: análise de um periódico de saúde e segurança do trabalho. 2009. 301f. Dissertaçâo (Mestrado) - Faculdade de Filosofia, Letras e Ciências Humanas, Universidade de Săo Paulo, São Paulo, 2009a. 
Interdiscursividade em artigos científicos.In: GARCIA, B. R. V.; SILVA, C. L. C. R; PIRIS, E. L. (Orgs.). Análises do Discurso: o diálogo entre as várias tendências na USP. Sáo Paulo, Paulistana, 2009b.

SOBRAL, A. Do dialogismo ao gênero: as bases do pensamento do Círculo de Bakhtin. Campinas: Mercado de Letras, 2009.

SOUZA, S. J.; ALBUQUERQUE, E. D. P. A pesquisa em ciências humanas: uma leitura bakhtiniana. Bakhtiniana, Săo Paulo, v. 7, n. 2, pp. 109-122, jul.-dez. 2012. Disponível em: 〈file:///C:/Users/usuario/Downloads/8124-30694-1-PB\%20(1).pdf〉._Acesso em: 10 maio 2014. 